\title{
OCCUPATIONAL CONTACT DERMATITIS AMONGST DENTISTS AND DENTAL TECHNICIANS
}

\author{
Liborija Lugović-Mihić ${ }^{1}$, Iva Ferček ${ }^{1}$, Tomislav Duvančić ${ }^{1}$, Vedrana Bulat ${ }^{1}$,Josip Ježovita ${ }^{2}$, \\ Gaby Novak-Bilić ${ }^{1}$ and Mirna Situm ${ }^{1}$
}

${ }^{1}$ Clinical Department of Dermatology and Venereology, Sestre milosrdnice University Hospital Center; ${ }^{2}$ Department of Sociology, Catholic University of Croatia, Zagreb, Croatia

\begin{abstract}
SUMMARY - Since the working medical personnel including dentists and dental technicians mainly use their hands, it is understandable that the most common occupational disease amongst medical personnel is contact dermatitis (CD) (80\%-90\% of cases). Development of occupational CD is caused by contact of the skin with various substances in occupational environment. Occupational etiologic factors for dental personnel are foremost reactions to gloves containing latex, followed by various dental materials (e.g., metals, acrylates), detergents, lubricants, solvents, chemicals, etc. Since occupational CD is relatively common in dental personnel, its timely recognition, treatment and taking preventive measures is needed. Achieving skin protection at exposed workplaces is of special importance, as well as implementing necessary measures consequently and sufficiently, which is sometimes difficult to achieve. Various studies have shown the benefit of applying preventive measures, such as numerous protocols for reducing and managing latex sensitivity and other forms of $\mathrm{CD}$ in dentistry. Active involvement of physicians within the health care system, primarily dermatologists, occupational medicine specialists and general medicine doctors is needed for establishing an accurate medical diagnosis and confirmation of occupational skin disease.
\end{abstract}

Key words: Dermatitis, contact; Dermatitis, occupational; Dentists; Dental auxiliaries; Hypersensitivity

\section{Introduction}

Dentistry implies high-risk procedures for the occurrence of professional contact dermatitis (CD). Dental professionals are exposed to numerous occupational substances that can be connected with the occurrence of CD. In 1954, Fisher and Woodside described the first cases of occupational methacrylate sensitization in dental personnel ${ }^{1}$. The prevalence of occupational CD in dental personnel has been steadily increasing over the last two decades and varies between $15 \%$ and $33 \%$, depending on various studies ${ }^{2}$. The use of occupational substances may cause both ir-

Correspondence to: Prof. Liborija Lugović-Mibić, MD, PhD, Clinical Department of Dermatology and Venereology, Sestre milosrdnice University Hospital Center, Vinogradska c. 29, HR-10000 Zagreb, Croatia

E-mail: liborija@gmail.com

Received March 12, 2015, accepted March 31, 2016 ritant $\mathrm{CD}$ and allergic $\mathrm{CD}$. Chemically active substances relevant to hygienic measures, as well as acrylates, composite resins, and latex gloves have all been increasingly put in direct connection with the occurrence of $\mathrm{CD}^{3}$. Skin affections in dental personnel are found mainly on the fingers and the hands, although secondary dissemination to other sites can occur. The most frequent clinical symptoms are scaling, erythema, vesicles, itching, and fissures ${ }^{4}$. This increasing prevalence of $\mathrm{CD}$ serves to highlight those areas where preventive efforts need to be made in order to reduce $C D$ associated with the workplace.

\section{Characteristics of Occupational Contact Dermatitis amongst Dental Professionals}

In many developed countries, including EU member countries, occupational skin diseases (OSDs) are 
one of the most common occupational diseases amongst dentists and dental technicians, second only to musculoskeletal disorders (MSDs) ${ }^{5}$. The vast majority of work-related dermatoses amongst dental personnel comprises of CD (80\%-90\% of cases) $)^{5}$.

Development of occupational CD is caused by contact of the skin with various substances in occupational environment. Overall, CD depends on the nature of work, working environment, condition of the skin prior to development of skin lesions, nature of substance(s) used in the work process, usage of protective clothing and equipment, exacerbation of skin lesions during work and their remission during longer periods of abstinence from work, as well as the success of previous therapies ${ }^{6}$. Occupational etiologic factors for dental staff are first and foremost reactions to gloves containing latex, followed by various dental materials, detergents, lubricants, solvents and chemicals ${ }^{7}$. The main cause for the occurrence of $\mathrm{CD}$ is contact of the skin with irritants and/or allergens, which leads to non-allergic (irritant or toxic) or allergic CD. Characteristics of irritant $\mathrm{CD}$, as opposed to allergic $\mathrm{CD}$, are the absence of immune reaction, no prior sensitization, and more frequent occurrence after exposure to certain substances. Also typical is the dose-dependence and, most commonly, non-involvement of non-exposed skin. The likelihood and severity of reaction depend on the nature and intensity of exposure to the etiologic factor. Irritant $C D$ is mostly related to skin barrier damage due to friction and various environmental factors (i.e. cold, excessive exposure to water or chemicals such as acids, alkalis, detergents and solvents) $)^{8}$. Such irritants remove fat and moisture (natural moisturizing factor) from the external surface, which enables them to penetrate more deeply, causing further damage associated with inflammation. Acute irritant $\mathrm{CD}$ is an acute inflammatory reaction of the skin associated with damage to the skin protective lipid layer and upper parts of the epidermis, and with toxic damage to the epidermis (primarily by impairment of the keratinocyte enzyme systems). The most common factors are aggressive chemicals, i.e. potent alkaline and acid substances, organic solvents (petrol, acetone, xylol, benzole), and others. The occurrence of dermatitis is very inconsistent and relies upon many factors, including the quantity and potency of the stimulus, duration and frequency of exposure, sensitivity of the skin (i.e. type of skin, previous skin lesion, or an already existing ten- dency to atopy) and various environmental factors (i.e. air temperature and humidity).

Skin lesions are often localized on the hands, forearms, face and neck. Clinical presentation of $\mathrm{CD}$ is characterized by a wide range of clinical features such as itching, erythema, vesiculation and papulovesicles (Fig. 1). Fissuring, hyperkeratosis and lichenification occur in chronic stages of the illness. It is important to note that, upon terminating contact with the occupational irritant, skin lesions withdraw, and relapse again after renewed exposure?

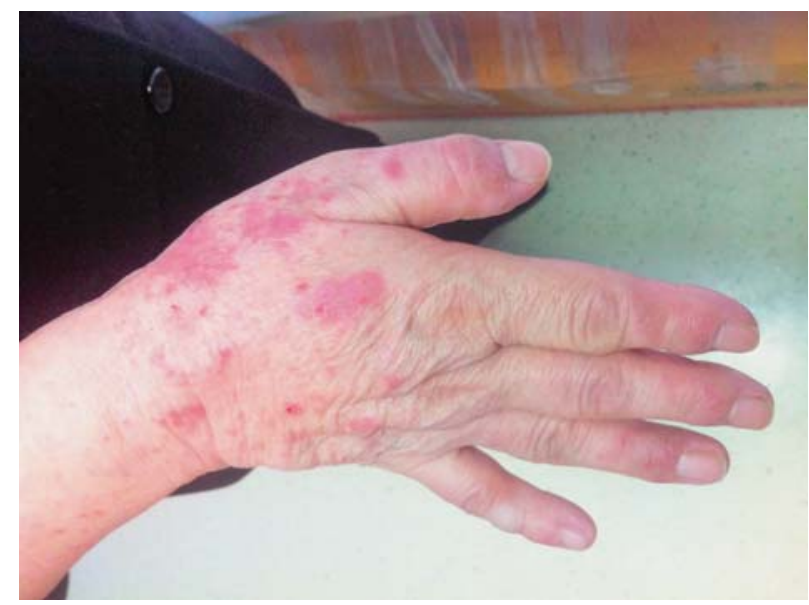

Fig. 1. Clinical presentation of acute contact dermatitis in a dentist.

It is important to emphasize that irritants are common everyday substances such as water, detergents, solvents, acids, alkalis, adhesives and liquids used for metal processing and friction. Several of these substances frequently act together to cause damage to the skin. Irritant $\mathrm{CD}$ is usually, at least in the beginning, confined to the location of irritant contact with the skin, with the possibility of spreading to non-affected areas in case of prolonged exposure or intense irritant effect. This is, however, less likely to occur than in allergic CD. Irritant CD may appear variably, in accordance with conditions of exposure. Following accidental exposure to a strong irritant, such as strong acids or alkalis, substances can cause acute CD, while persistent contact with a weak irritant (such as water and soap or detergent) may cause chronic $\mathrm{CD}$ within several weeks.

Irritant $\mathrm{CD}$ is common in medical professionals, doctors, nurses, midwives, dentists, laboratory techni- 
cians and others. CD is generally caused by frequent hand washing (in water), gloves, soaps, aggressive disinfectants or detergents, pitch and adhesives, as well as nickel which is present in metal parts of medical instruments $^{6}$. It is of special importance due to the fact that medical professionals such as dentists are engaged in so-called wet work, which is well known for increasing the tendency towards professional irritant $\mathrm{CD}$, primarily because of the frequent and repeated exposure to water. In this case, water acts as a mild irritant that extracts lipids of the stratum corneum, which leads to cracking and formation of fissures. Wet work is defined as exposure of the skin to liquids for more than 2 hours a day or work that includes very frequent hand washing ( $>20$ times/day or less if the procedure is more aggressive $)^{5}$. The prevalence of dermatoses amongst dentists varies between $15 \%$ and $33 \%$, depending on various studies ${ }^{2}$.

If these acute skin lesions persist, the condition progresses to the chronic form of $\mathrm{CD}$. Chronic irritant $\mathrm{CD}$ is usually a consequence of repeated influences of weak irritants on the skin, leading to additional harmful effects. Such a destructive effect is continuing and accumulating, thus gradually changing, damaging and removing the skin protective barrier (lipid film layer on the surface of corneal layer, acidic $\mathrm{pH}$ of that film, corneal layer). It has been observed that changes are more common in patients with dry skin and hereditary diseases (i.e. ichthyosis, atopic dermatitis). Clinically, the skin on such exposed areas (hands, fingers, etc.) becomes dry and reddish, with slight inflammatory infiltrates, and the appearance of desquamation and rhagades. Skin lesions are usually not sharply bordered on the unaffected parts of the skin.

On the other hand, similar skin lesions are present in allergic $\mathrm{CD}$, whereby a complex pathogenic mechanism and type IV allergic hypersensitivity occur. The process includes interaction between contact allergens, Langerhans cells (LCs) and in some cases dendritic cells (DCs), lymphatic system, regional lymph nodes, presentation of antigen to $\mathrm{T}$ cells controlled by cytokines and chemokines, with tumor necrosis factor alpha (TNF- $\alpha$ ) and certain members of the interleukin family ${ }^{5,10}$.

The diagnosis is based on work history, clinical presentation and patch test. Patch test is a well-established method of diagnosing allergic CD. In order to identify causative substances for occupational CD, the patient's work history and personal medical history should be taken, the patient's workplace and materials from their work environment analyzed, and patch testing performed. Patch testing with standard and dental allergens can be considered to cover the present exposure situation in the occupational setting. However, the allergens are pure chemicals and, if one suspects that a degradation product has caused $\mathrm{CD}$, the cause will be missed. A supplementary test with the patient's own working material is therefore recommended ${ }^{11}$.

Treatment of occupational CD depends on the clinical presentation and corresponds to the treatment of non-occupational CD. Aside of emollient creams and ointments, various topical corticosteroids, keratolytics and other agents are usually used during the inflammatory phase. Since occupational exposure is considered to be the cause of these lesions, full protection is needed, as well as change of the technological processes or use of personal protection, which would in effect prevent the emergence of skin changes. If these working conditions cannot be provided, change of the workplace is needed ${ }^{11}$.

\section{Prevalence of Occupational Dermatoses}

Occupational skin diseases affect workers of all ages in various working conditions, but sometimes these dermatoses are poorly reported since their relationship with the particular occupation is usually not recognized. Still, in general, CD is attributed to specific agents depending on the occupation ${ }^{5}$.

Several studies show various results regarding the prevalence of CD. In a Swedish study, about 15\% of dentists reported hand eczema, in one Thai study occupational CD was demonstrated in $22 \%$ of dentists, even more frequently in New Zealand (one-third of dentists reported hand dermatoses), also in Great Britain, in Queensland, Australia, as well as in Norway $^{2,12-14}$. As to sex distribution, occupational dermatoses are more common in women, as well as in younger and less experienced dentists ${ }^{12-14}$. It was also observed that dentists with a history of allergic conditions had a higher prevalence of hand dermatitis, as well as those with hobbies that include the use of solvents ${ }^{2}$.

One comprehensive research on the prevalence of self reported skin diseases related to occupation, which was performed in 39000 workers in Great Britain (in 2001-2002) showed a yearly average of 3900 new cases 
diagnosed by dermatologists and occupational medicine specialists (EPIDERM, Professional skin surveillance and OPRA, Reports of occupational medicine specialists $)^{5,15}$. A frequently emphasized problem is allergy to latex gloves, which is reported in various studies all over the world as the most common cause of dermatitis in dental personne ${ }^{16,17}$. However, studies have been conducted that point out that only $4 \%$ to $6 \%$ of dental personnel are truly positive to latex ${ }^{18}$.

A significant Polish study on skin disease related to occupation, performed by Kurpiewska et al., investigated the prevalence of self reported skin symptoms on hands and forearms amongst various professionals (medical workers, hairdressers, cosmeticians, food industry workers, cleaners, metal workers and textile industry workers). Results showed the skin disorders to be most common in medical workers, i.e. $86 \%$ of dentists, $67 \%$ of midwives, $51 \%$ of medical nurses and $41 \%$ of physicians ${ }^{5}$. These results also revealed the issues with latex gloves to have been reported by $30 \%$ of medical personnel ${ }^{5}$.

\section{Reactions to Latex}

Most dentists nowadays routinely wear gloves during their work, which are mostly made of latex that significantly reduces the risk of HIV/blood related diseases, but sometimes causes skin lesions ${ }^{19}$. Latex that is used for glove manufacturing is extracted from the plant Hevea brasiliensis which contains certain strong allergens, but also important are the chemicals used for the manufacture and sterilization of gloves, which can also act as contact allergens ${ }^{20}$. The etiology of hypersensitivity to latex is based on the reaction to the plant that contains natural rubber protein allergens and on reactions that may cause $\mathrm{IgE}$-mediated type I hypersensitivity (which may be severe and only exceptionally fatal) and type IV hypersensitivity (development of $\mathrm{CD})^{7}$.

Global reports on the occurrence of allergy to latex gloves in general population vary from $6 \%$ to $12 \%$, and in medical workers from $3 \%$ to $22 \% 19,21,22$. These data differ from one study to another. It became apparent that $4 \%$ to $10 \%$ of dental personnel and senior dental students were positive to latex allergy, whereas earlier dental studies showed real allergy to latex to be medically diagnosed in only $2 \%$ of dentists (which was less than in other studies) ${ }^{23}$.
A significant research in India on the occurrence of allergy to latex gloves in 163 dentists (73\% male and 27\% female), performed by Agrawal et al., used a selfadministered pre-testing questionnaire ${ }^{19}$. Results showed $16 \%$ of dentists to be allergic to latex gloves, which is in concordance with other studies ${ }^{10,16,24,25}$. A rise in the occurrence of allergies to latex gloves amongst dentists was shown, as well as these allergies to occur more often in women $(27.3 \%$ of women vs. $11.8 \%$ of men), although other studies did not demonstrate any significant bias according to this parame$\operatorname{ter}^{19,20}$. The occurrence of allergies to latex gloves was significantly higher when latex gloves were used for a greater number of years, as well as in individuals with allergies to cereal pollen, food products and protective rubber, and those having asthma, eczema, or a family history of allergies ${ }^{19,22,24}$. According to some investigations, the greatest incidence of occupational sensitization occurs in the first two years of exposure ${ }^{26}$.

A significant research was performed by the American Dental Association (ADA) exploring the incidence of type I hypersensitivity to latex in over 2000 dentists and other support dental personnel who participated in testing during the ADA annual meetings in 1994 and 1995 . The results showed that $6.2 \%$ of participants were positive to type I hypersensitivity to latex. Subsequent research showed a decline in the incidence from $8.5 \%$ to $4.3 \%$, which was related to using latex gloves of better quality with lesser amounts of allergens $s^{7,21,27,28}$. A study performed in Great Britain on the side effects of latex gloves among dentists revealed that the majority of allergies to latex could be controlled by self-medication, prescribed therapy and/or changing to other types of gloves ${ }^{29}$. Successful preventive programs were also introduced in order to decrease the incidence of allergies to latex or other dental materials (i.e. acrylates). Nevertheless, for the purpose of accurate diagnosis of occupational latex allergy, every dentist with a preliminary diagnosis of this condition should be referred for a more detailed allergy testing ${ }^{2}$.

Research has also shown the benefits of frequent hand washing after using latex gloves, as it removes irritants that cause these reactions, while the effect of using glove powder has not been proven ${ }^{19,20}$.

The most important elements for the diagnosis of latex glove allergy are history, physical examination and diagnostic testing. The $\mathrm{IgE}$ mediated hypersensitivity to latex allergens is hereby usually determined 
(skin testing or in vitro assay for specific $\operatorname{IgE}$ antibodies $)^{19}$. Appropriate allergy testing is particularly important due to the correlation between latex glove allergy and history of allergy and atopy (especially allergy to cereal pollen) ${ }^{22}$.

Avoiding contact with products that contain natural rubber latex is crucial for treatment, but this can be very difficult since such products are quite ubiquitous. These persons should use latex free gloves whenever possible, i.e. vinyl or nitrile gloves (although these are not as effective for hepatitis or HIV protection as latex gloves) or other synthetic gloves which prevent disease transmission, as well as rubber gloves (although they can be much more expensive). For some people with $\mathrm{CD}$, it is possible to wear latex gloves that do not contain other chemicals. Furthermore, frequent hand washing after the use of gloves is recommended, as well as the usage of appropriate skin care (hydrating creams or ointments), while for periods of worsening, topical corticosteroids and sometimes systemic antihistamines are usually applied ${ }^{19,29}$. In some countries, local state authorities participate in the prevention of these disorders through regulatory actions that reduce the risk of latex products in health workers and $\mathrm{pa}^{-}$ tients. Thus, various federal agencies have displayed rules and recommendations about product selection, work procedures for risk reduction, staff education and follow up of allergy symptoms (i.e. Food and Drug Administration (FDA), National Institute for Occupational Safety and Health (NIOSH), Occupational Safety and Health Administration (OSHA) and Centers for Disease Control and Prevention $(\mathrm{CDC}))^{7}$. FDA therefore requires all medical/dental products that contain latex to be clearly labeled as to "contain latex"7.

It should be emphasized that awareness of the problem is most important, as well as its recognition and diagnosing. Dental workers should therefore be familiar with the signs and symptoms of sensitivity to latex, while the physician in charge should estimate these symptoms and then make the diagnosis based on the patient's history, physical examination and diagnostic tests.

\section{Reactions to Other Substances}

Reports from Europe and the United States suggest that the most common cause of allergies among dentists are gloves and dental restorative plastic materials. Aside from reactions to latex, occupational hand $\mathrm{CD}$ among dentists may also be a result of exposure to various chemical and dental materials, foremost to metals and acrylates (i.e. methyl methacrylate and cyanoacrylate), whereby contact allergic reaction is proven by patch testing ${ }^{2}$.

A more recent Turkish study assessed the frequency of CD and materials that cause contact sensitization (by using patch test) in 461 dental personnel (technicians, dentists and medical nurses) ${ }^{30}$. In this study, 198 (43\%) dental personnel members were proven to have $\mathrm{CD}$, while 67 had given their consent to testing (European standard series), which showed positive reactions to at least one allergen in $20 \%$ and to a dental series in $10.8 \%$ of cases. The most common proven allergens were nickel sulfate (12.3\%), acrylates (6.1\%) and para-tertiary-butylphenol-formaldehyde resin (4.6\%) (most common reactions were to ethylene glycol dimethacrylate (3.1\%)).

Metals were, therefore, next to latex, another common potential cause of contact allergic dermatitis ${ }^{31,32}$. Thus, Khamaysi et al. included dental personnel with hand dermatitis in the research of contact allergic reactions, but only $39 \%$ of them were positive on patch test, mostly to metals, i.e. nickel, gold, palladium and cobalt ${ }^{31}$. It was shown that hand dermatitis in dental workers is relatively commonly caused by metal allergies, although it is possible that dental instruments alone are not the only source of activation but rather a key factor in the occurrence of $\mathrm{CD}^{31}$. Lee et al. have also reported similar results in 49 dental technicians in Korea $^{33}$.

A significant new study emerged that investigated contact allergy among dental personnel and patients with oral disorders who had come in contact with these materials ${ }^{34}$. Research in dental personnel with a history of hand dermatitis (patch testing) showed multiple allergies to various dental materials, and multiple standard allergens ( $\mathrm{NN}$-dimethyl-p-toluidine, 2 hydroxy-4-methoxybenzophenone, methylhydroquinone, nickel sulfate, copper sulfate, palladium, methyl methacrylate, ethylene glycol dimethacrylate, and 1,4-butanediol dimethacrylate) ${ }^{34}$.

Among other significant reactions, allergic $C D$ caused by acrylates and methacrylates stands out for causing occupational and non-occupational allergic CD. Several investigations of contact allergies to 
(meth)acrylates among dental personnel have been performed ${ }^{35,36}$. In dentistry, acrylics are used to make dentures and other prostheses, for repair of fractured prostheses, and they are strong occupational sensitizers (especially for dental personnel). Acrylic monomersacrylates (potent sensitizers whose capacity reduces significantly after polymerization), methacrylates, urethane acrylates and epoxy acrylates are used in dentistry in prostheses, dental adhesives, dental connective materials and glass ionomers. During the 1990s, a significant increase in contact allergies to methacrylates was recorded, as well as occupational allergies to acrylic monomers ${ }^{35}$. Allergic CD caused by acrylates and methacrylates is traditionally considered to be primarily an occupational disease that mostly occurs amongst dental personnel, but also in other practices. Previous studies have reported that $5 \%-25 \%$ of dental personnel could be sensitized to (meth)acrylates ${ }^{37}$. Protection gloves are hereby usually not effective, since (meth)acrylate monomers penetrate through the rubber surface of gloves, and $4 \mathrm{H}^{\oplus}$ gloves (North Safety by Honeywell) or $4 \mathrm{H}^{\oplus}$ 'fingers' are not suitable for performing delicate procedures. The most common allergens overall are 2-hydroxyethyl methacrylate (HEMA) and 2-hydroxypropyl methacrylate (HPMA), followed by 2-hydroxyethyl acrylate and ethylene glycol dimethacrylate (EGDMA).

Another important research was performed by Aalto-Korte et al., showing that dentists and dental technicians were most commonly exposed to 2-hydroxyethyl methacrylate (2-HEMA), triethylene glycol dimethacrylate (TREGDMA) and 2,2-bis[4-(2hydroxy-3 methacryloxypropoxy)phenyl]propane (bisGMA) ${ }^{35}$. Dental technicians were mostly exposed and sensitized to methyl methacrylate (MMA) and EGDMA $^{35}$.

Dentists and dental technicians also handle dental composite resins (DCRs), which are used for restoration work including filling, bridges and crowns, and many other aspects of cosmetic dentistry. Thus, allergic CD to DCRs has been observed in dental personnel, although less frequently than acrylate allergy ${ }^{19}$.

Notable, among other substances are reactions to thiurams and dithiocarbamates (included in patch test as thiuram mix), which are common in natural and synthetic rubber products ${ }^{38}$. A high risk of such a sensitivity has been observed in medical workers (doctors and dentists), in care personnel and personnel em- ployed in fish and meat processing, as well as in cleaners. Follow ups in health workers have, nevertheless, recorded a significant trend of decreasing, which can possibly be explained by good accessibility to diagnostics and treatment ${ }^{38}$.

\section{Conclusion}

Occupational CD is relatively common in dental personnel, thus timely recognition, treatment and taking preventive measures is needed. Achieving skin protection at exposed workplaces is of special importance, as well as implementing measures consequently and sufficiently, which is sometimes difficult. Various studies have shown the benefits of applying preventive measures, such as numerous protocols for reducing and managing latex sensitivity and other forms of $\mathrm{CD}$ in dentistry. Active involvement of physicians within the health care systems, primarily dermatologists, occupational medicine specialists and general medicine doctors, is needed to establish an accurate medical diagnosis and confirm an occupational skin disorder and disease. Reducing exposure to the potential allergens and irritants is the key to minimizing this risk.

\section{References}

1. Fisher AA, Woodside NY. Allergic sensitization of the skin and oral mucosa to acrylic denture materials. JAMA. 1954; 156:238-42.

2. Leggat PA, Kedjarune U, Smith DR. Occupational health problems in modern dentistry: a review. Ind Health. 2007; 45(5):611-21.

3. Dahlin J, Bergendorff O, Vindenes HK, Hindsen M, Svedman C. Triphenylguanidine, a new old (old?) rubber accelerator detected in surgical gloves that may cause allergic contact dermatitis. Contact Dermatitis. 2014;71:242-6. doi: 10.1111/ cod. 12276

4. Lindberg M, Silverdahl M. The use of protective gloves and the prevalence of hand eczema, skin complaints and allergy to natural rubber latex among dental personnel in the county of Uppsala, Sweden. Contact Dermatitis. 2000;43(1):4-8.

5. Kurpiewska J, Liwkowicz J, Benczek K, Padlewska K. A survey of work-related skin diseases in different occupations in Poland. Int J Occup Saf Ergon. 2001;17(2):207-14

6. Bensefa-Colas L, Telle-Lamberton M, Paris C, et al. Occupational allergic contact dermatitis and major allergens in France: temporal trends for the period 2001-2010. Br J Dermatol. 2014;17(16):1375-85. doi: 10.1111/bjd.13133. 
7. Ayatollahi J, Ayatollahi F, Ardekani AM, Bahrololoomi R, Ayatollahi J, Owlia MB. Occupational hazards to dental staff. Dent Res J (Isfahan). 2012;9(1):2-7. doi: 10.4103/17353327.92919.

8. Morris-Jones R, Robertson SJ, Ross JS, White IR, McFadden JP, Rycroft RJ. Dermatitis caused by physical irritants. Br J Dermatol. 2002;147(2):270-5.

9. Geier J, Lessmann H, Mahler V, Pohrt U, Uter W, Schnuch A. Occupational contact allergy caused by rubber gloves - nothing has changed. Contact Dermatitis. 2012;67(3):149-56. doi: 10.1111/j.1600-0536.2012.02139.x.

10. Liss GM, Sussman GL, Deal K, Brown S, Cividino M, Siu S. Latex allergy: epidemiological study of 1351 hospital workers. Occup Environ Med. 1997;54:335-42.

11. Holness DL. Occupational skin allergies: testing and treatment (the case of occupational allergic contact dermatitis). Curr Allergy Asthma Rep. 2014;14(2):410. doi: 10.1007/s11882-0130410-8.

12. Wallenhammar LM, Ortengren U, Andreasson H, et al. Contact allergy and hand eczema in Swedish dentists. Contact Dermatitis. 2000;43:192-9.

13. Sinclair NA, Thomson WM. Prevalence of self-reported hand dermatoses in New Zealand dentists. N Z Dent J. 2004;100: 38-41.

14. Burke FJ, Wilson NH, Cheung SW. Factors associated with skin irritation of the hands experienced by general dental practitioners. Contact Dermatitis. 1995;32:35-8.

15. Medical aspects of occupational skin disease (Guidance Note MS 24). $2^{\text {nd }}$ ed. Sudbury: HSE Books; 1998.

16. Katelaris CH, Widmer RP, Lazarus RM. Prevalence of latex allergy in a dental school. Med J Aus. 1996;164:711-4.

17. Leggat PA, Smith DR. Prevalence of hand dermatoses related to latex exposure amongst dentists in Queensland, Australia. Int Dent J. 2006;56:154-8.

18. Hamann CP, Turjanmaa K, Rietschel R, Siew C, Owensby D, Gruninger SE, Sullivan KM. Natural rubber latex hypersensitivity: incidence and prevalence of type I allergy in the dental profession. J Am Dent Assoc. 1998;129:43-54.

19. Agrawal A, Bhatt N, Kk S, Singh K, Chaundhary H, Asawa K. Prevalence of allergy to latex gloves among dental professionals in Udaipur, Rajasthan, India. Oral Health Prev Dent. 2010; 8(4):345-50.

20. Khader Y, Abu-Zaghlan M, Abu-Al Rish I, Burgan S, Amarin Z. Self-reported allergy to latex gloves among health care workers in Jordan. Contact Dermatitis. 2005;53(6):339-43.

21. Turjanmaa K, Kanto M, Kautiainen H, Reunala T, Palosuo T. Long-term outcome of 160 adult patients with natural rubber latex allergy. J Allergy Clin Immunol. 2002;110(2):70-4.

22. Garabrant DH, Schweitzer S. Epidemiology of latex sensitization and allergies in health care workers. J Allergy Clin Immunol. 2002;110(2):82-95.

23. Tarlo SM, Sussman GL, Holness DL. Latex sensitivity in dental students and staff: a cross-sectional study. J Allergy Clin Immunol. 1997;99:396-401.
24. Kaczmarek RG, Silverman BG, Gross TP, Hamilton RG, Kessler E. Prevalence of latex-specific IgE antibodies in hospital personnel. Ann Allergy Asthma Immunol. 1996;76(1):51-6.

25. Watts DN, Jacobs RR, Forrester B, Bartolucci A. An evaluation of the prevalence of latex sensitivity among atopic and nonatopic intensive care workers. Am J Ind Med. 1998;34(4): 359-63.

26. Archambault S, Malo JL, Infante-Rivald C, Ghezzo H, Gautrin D. Incidence of sensitization, symptoms, and probable occupational rhinoconjunctivitis and asthma in apprentices starting exposure to latex. J Allergy Clin Immunol. 2001;107(5): 921-3.

27. Hunt LW, Kelkar P, Reed CE, Yunginger JW. Management of occupational allergy to natural rubber latex in a medical center: the importance of quantitative latex allergen measurement and objective follow-up. J Allergy Clin Immunol. 2002;110(2): 96-106.

28. Saary MJ, Kanani A, Alghadeer H, Holness DL, Tarlo SM. Changes in rates of natural rubber latex sensitivity among dental school students and staff members after changes in latex gloves. J Allergy Clin Immunol. 2002;109:131-5.

29. Scott A, Gawkrodger DJ, Yeoman C, Egner W, van Noort R, Halton PV, Grummitt J. Adverse reactions to protective gloves used in the dental profession: experience of the UK Adverse Reaction Reporting Project. Br Dent J. 2003;195(12):686-90.

30. Kocak O, Gul U. Patch test results of the dental personnel with contact dermatitis. Cutan Ocul Toxicol. 2014;33(4):299-302. doi: 10.3109/15569527.2013.866132.

31. Khamaysi Z, Bergman R, Weltfriend S. Positive patch test reactions to allergens of the dental series and the relation to the clinical presentations. Contact Dermatitis. 2006;55:216-8.

32. Turčić $P$, Marinović Kulišić S, Lipozenčić J. Patch test reactions to metal salts in patients with different types of dermatitis. Acta Dermatovenerol Croat. 2013;21(3):180-4.

33. Lee JY, Yoo JM, Cho BK, Kim HO. Contact dermatitis in Korean dental technicians. Contact Dermatitis. 2001;45(1):13-6.

34. Rai R, Dinakar D, Kurian SS, Bndoo YA. Investigation of contact allergy to dental materials by patch testing. Indian Dermatol Online J. 2014;5(3):282-6. doi: 10.4103/2229-5178.137778.

35. Aalto-Korte K, Alanko K, Kuuliala O, Jolanki R. Methacrylate and acrylate allergy in dental personnel. Contact Dermatitis. 2007;57:324-30.

36. Wrangsjö K, Swartling C, Meding B. Occupational dermatitis in dental personnel: contact dermatitis with special reference to (meth)acrylate in 174 patients. Contact Dermatitis. 2011; 45:158-63.

37. Ramos L, Cabral R, Gonçalo M. Allergic contact dermatitis caused by acrylates and methacrylates - a 7-year study. Contact Dermatitis. 2014;71(2):102-7. doi: 10.1111/cod.12266.

38. Uter W, Hegewald J, Pfahlberg A, Lessmann H, Schnuch A, Gefeller O. Contact allergy to thiurams: multifactorial analysis of clinical surveillance data collected by the IVDK network. Int Arch Occup Environ Health. 2010;83(6):675-81. doi: 10.1007/ s00420-009-0503-9. 


\section{Sažetak \\ PROFESIONALNI KONTAKTNI DERMATITIS KOD STOMATOLOGA I STOMATOLOŠKIH TEHNIČARA}

\section{Lugović-Mihic, I. Ferček, T. Duvančic, V. Bulat, J. Ježovita, G. Novak-Bilić i M. Šitum}

Budući da se medicinsko osoblje, uključujući stomatologe i stomatološke tehničare, uglavnom služi svojim rukama, razumljivo je da je najčešća profesionalna bolest kontaktni dermatitis $(\mathrm{KD})$ šaka (80\%-90\% slučajeva). Na razvoj profesionalnog KD šaka utječe dodir kože s različitim tvarima u profesionalnom okolišu. Profesionalni uzročni čimbenici za stomatološko osoblje su ponajprije reakcije na rukavice koje sadrže lateks, slijede ih različiti stomatološki materijali (npr. metali, akrilati), deterdženti, lubrikanti, otapala, kemikalije itd. Profesionalni KD relativno je čest u stomatološkog osoblja, stoga je potrebno pravodobno prepoznavanje, liječenje i preventivne mjere. Postizanje zaštite kože kod izloženih radnih mjesta od posebne je važnosti, kao i uključivanje mjera postupno i dostatno, što je katkada teško provesti. Različite studije pokazale su korist od primjene preventivnih mjera kao što su brojni postupci za smanjivanje i svladavanje osjetljivosti na lateks i ostale oblike KD u stomatologiji. Aktivno sudjelovanje liječnika u medicinskoj zaštiti, prvenstveno dermatologa, specijalista medicine rada kao i liječnika obiteljske medicine potrebno je za donošenje odgovarajuće medicinske dijagnoze i potvrdu profesionalne bolesti kože.

Ključne riječi: Dermatitis, kontaktni; Dermatitis, profesionalni; Stomatolozi; Stomatološko pomoćno osoblje; Alergija 